\title{
Comparative Studies Of Three Formulated Artificial Litchi Flavored Drinks Under Storage
}

\author{
Abu Saeid*, Niebaron Kumar Deb, Eliyas, Sree Surozit Sarkar, Milon Debnath, Md. Taherul Islam and Md. Tawhidul Islam
}

Department of Food Engineering, NPI University of Bangladesh, Manikganj, Bangladesh

*Corresponding Author Email: saeidfpp.hstu@gmail.com

\section{Doi: 10.2478/mjhr-2021-0005}

\section{Abstract:}

The aim to the present study was to formulate of artificial litchi flavored drinks, to assess quality parameters like pH, acidity, TSS and sensory characteristics of three formulated artificial litchi flavored drinks were investigated under 28 days of storage at ambient $\left(30 \pm 2^{\circ} \mathrm{C}\right)$ temperature. The $\mathrm{pH}$ values for all samples varied from 3.53 to 3.65 under the entire storage duration. The acidity found in three different samples ranged from 0.155 to $0.161 \%$ under storage condition. The TSS possess among the samples between 15.43 to $16.10^{\circ}$ Brix. The sensory profile of three different formulation was evaluated in terms of color, flavor, taste and overall acceptability. The sensory parameters were followed the decreasing trend after end of the storage except sample 3. Although, initially sample 3 found in lowest sensory acceptance but retained the more stable score under the entire storage period which is significantly different $(\mathrm{P} \leq 0.05)$ from other samples. Considering $\mathrm{pH}$, acidity, TSS values under entire storage condition the formulation of sample 3 had shown better results although with few exceptions there was no significant difference $(\mathrm{P} \leq 0.05)$ among the samples. However, end of the study we recommended that, the formulation of sample 3 had better among other sample 1 and sample 2 in terms of quality and cost.

Keywords: Artificial flavored Litchi drinks, pH, Acidity, TSS and Sensory Evaluation.

\subsection{Introduction}

Lychee (Litchi chinensis Sonn.) is one of the most important sub-tropical evergreen fruit trees, grow well in Bangladesh which originated in southern China and possibly northern Viet Nam belongs to the Sapindaceae family [1]. It is a highly priced, popular and major table fruit in Bangladesh. Fresh lychee is always very high demand due to its unique taste, flavor and color. A rich source of vitamin C, litchi contains a fair amount of phosphorus, Calcium, Iron, Vitamin A and B. Litchi pulp contains $15.9 \%$ seed, $9.6 \%$ pericarp, $74.5 \%$ edible portion, $78.2 \%$ moisture, $1.2 \%$ acid, $0.97 \%$ oil, $0.94 \%$ protein, $0.69 \%$ ash, $6.89 \%$ free reducing sugars, $6.68 \%$ hydrolysable sugars and $13.75 \%$ total sugars [1]. Litchis are generally eaten fresh, but can also be consumed as other litchi-based products like dried litchi, canned litchi, frozen litchi, litchi honey, litchi wine, health beneficial litchi drinks to name a few have been documented [2]. Litchi also utilize for the development of different value-added products like jelly, juice and squash [1].

Nowadays, fruit drink is synthetically produced with artificial flavor like lychee, strawberry, orange etc. and bottled as well as sold in the market. Prepared drink (beverage) are also in high demand due to their thirst quenching, nutritious, easily digestible, appetizing, and highly refreshing properties for human intake. Although fruit juice is far better than synthetic or artificial fruit drink that are available in market which is considered as high calorific value make them popular and acceptable as well as meet the current demand of the population [3]. Development of artificial drink utilizing by the local producer is significantly important for expanding the country's ever-growing food companies.

Usually, artificial flavored drink contained with sugar, stabilizer (like Macogel, Carboxy Methyl Cellulose (CMC), citric acid, sodium benzoate, Potassium sorbet, and permitted artificial fruit flavor and concentrate. In the market, flavored drinks specially litchi drink contained high-cost stabilizer like macogel, CMC but same quality product will be introduced using compound stabilizer instead of macogel and CMC that might be reduced cost of the products. Considering the above-mentioned fact, an attempt was taken to develop an artificial litchi flavored drink to meet the consumer preference beside cost effective product using compound stabilizer instead of macogel and CMC. The objective of the present study was to formulate of artificial litchi flavored drinks, to assess the quality parameters and to evaluate the consumer acceptance under four weeks of storage.

\subsection{Materials and Method}

\subsection{Sample collection and preparation}

All raw materials were purchased from the local market, Dhaka, Bangladesh. In the laboratory, raw materials were weighed according to the formulation and packed with polyethylene bag until use.

\subsection{Chemical and reagents}

Sugar, Macogel, CMC, Compound stabilizer, citric acid, sodium benzoate, potassium sorbet, and permitted artificial litchi flavor and litchi concentrate etc. were used in this study.

Table 1. Formulation of artificial litchi flavored drinks

\begin{tabular}{|l|l|l|l|l|}
\hline SL. No & Ingredients & Sample 1 (\%) & Sample 2 (\%) & Sample 3 (\%) \\
\hline 01 & Sugar & 16.00 & 16.00 & 16.00 \\
\hline 02 & *Macogel/CMC/Compound stabilizer & 0.08 & 0.08 & 0.08 \\
\hline 03 & Ascorbic acid & 0.012 & 0.012 & 0.012 \\
\hline 04 & Citric acid & 0.16 & 0.16 & 0.16 \\
\hline 05 & Sodium benzoate (20\% N Solution) & 0.0962 & 0.0962 & 0.0962 \\
\hline 06 & Potassium sorbet (20\% N Solution) & 0.035 & 0.035 & 0.035 \\
\hline 07 & Litchi emulation \& Flavor & 0.100 & 0.100 & 0.100 \\
\hline 08 & Litchi concentrate & 0.800 & 0.800 & 0.800 \\
\hline 09 & Water & 83.54 & 83.54 & 83.54 \\
\hline
\end{tabular}

*For sample 1 used Macogel, sample 2 used CMC and sample 3 used compound stabilizer 


\subsection{Preparation of artificial litchi flavored drinks}

The sucrose is added to the purified water at $2: 3$ ratios in a syrup preparation tank and heated $\left(70-80^{\circ} \mathrm{C}\right)$ until dissolved completely, then strained and sufficient purified water added to make the desired weight or volume. Blending for 60 minutes and maintain the final brix at $60^{\circ}$. During cooking, syrup mixed with water, fresh Litchi concentrate and blending for few minutes and add Sodium benzoate then add Citric Acid, Ascorbic acid, Potassium Sorbet, Macogel, CMC, Compound stabilizer. Mixing the ingredients at steam pressure $0.5-1.5 \mathrm{~kg} / \mathrm{cm}^{2}$ and temperature (80-85) ${ }^{\circ} \mathrm{C}$. After $30-35 \mathrm{minutes} \mathrm{later} \mathrm{check}$ the brix if get as per required then add color and flavor. Then filtered by SS net and transfer to the reserved tank. After cooking the mixture send to the filling machine through pipe line. And it's falls into the poly propylene cup by filling valve. During filling, temperature $(40-45){ }^{\circ} \mathrm{C}$ is maintained. After filling the product sealed at $200-220^{\circ} \mathrm{C}$. Then it pasteurized at $85^{\circ} \mathrm{C}$ for 15 minutes. End of the pasteurization, the product pass through the cooling tank and cooling at temperature $\left(38^{\circ} \mathrm{C}\right)$ using normal water for 4 to $5 \mathrm{~min}$. After cooling operation, the product become wet and drying by air blower for 4 to 5 minutes. Finally, dried product fill into suitable package (Figure 1).

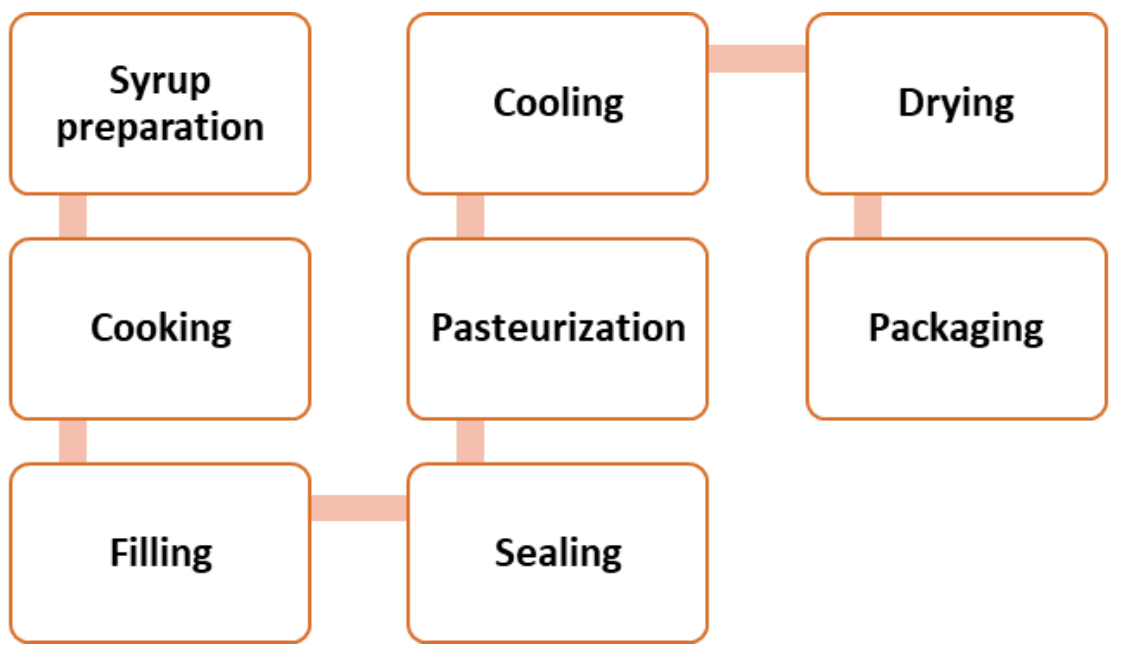

Figure 1. Flow diagram of Artificial litchi flavored drinks

\subsection{Determination of $\mathrm{pH}$}

The $\mathrm{pH}$ of artificial litchi flavored drink was measured by a pH meter (Hanna Instruments, HI 8417, Italy) calibrated using buffers of pH 7.0 and 4.0. Then the $\mathrm{pH}$ of the samples was recorded.

\subsection{Determination of Acidity/Titratable Acidity}

Acidity of artificial litchi flavored drinks was determined according to the method reported with few modifications [4]. 5 ml of sample was diluted to 95 ml of de-ionized-distilled water. $10 \mathrm{~mL}$ diluted sample was taken in conical flask. After that, 2-3 drops of phenolphthalein indicator were added to the flask. Then the solution was titrated against $0.1 \mathrm{~N} \mathrm{NaOH}$ solution until the end point is reached. The acid content of the sample was calculated based on the volume of $0.1 \mathrm{~N} \mathrm{NaOH}$ used for neutralizing the acid content in the sample and multiplying by a correction factor of 0.064 to estimate titratable acidity as percentage of citric acid. The titratable acidity was calculated using the following equation

$\%$ Acidity $=\frac{\mathrm{ml} \mathrm{NaOH} \times 0.1 \mathrm{~N} \mathrm{NaOH} \times 0.064}{\text { Volume of Sample }} \times 100$

\subsection{Determination of Total Soluble Solid (TSS)}

The TSS ( ${ }^{\circ}$ Brix) of the artificial litchi flavored drink were determined by using a handheld refractometer (Model: HT119-ATC).

\subsection{Sensory Evaluation}

Sensory characteristics of artificial litchi flavored drink sample was carried out on 28 days of storage. Semi-trained fifteen panel members were selected from the University community. Randomly, the samples were presented to the panel members. Artificial litchi drink samples were evaluated organoleptically for color, flavor, taste and overall acceptability, according to the hedonic scale of nine points (9-like extremely to 1- dislike extremely) as reported [5].

\subsection{Statistical Analysis}

Data were analyzed statistically using the statistical software R (windows version 2.13.1). All results were measures triplicate for each sample. Results were expressed as mean values with standard deviation $( \pm$ SD). DMRT (Duncan Multiple Range Test) was performed to evaluate the significance of difference between mean values at the level of $5 \%$.

\subsection{Results and Discussion}

\section{1.pH values of artificial litchi flavored drinks during storage}

The $\mathrm{pH}$ values of artificial litchi flavored drinks shown in (figure 2) under storage condition. The values of $\mathrm{pH}$ in artificial litchi drink varied from 3.53 to 3.65 for all samples during entire storage duration. The highest $\mathrm{pH}$ value found in sample 3 and lowest in sample 1 . The $\mathrm{pH}$ values of sample 1 and sample 3 has reduced in the end of the storage except sample 2. Although $\mathrm{pH}$ values for all samples varied from day to day but there is no significantly (P $\leq 0.05$ ) different found among them either samples or storage. Our obtained $\mathrm{pH}$ value was higher than the normal litchi juice was 3.10 [6]. The value is comparable with the work of who reported the different fruit drink's pH varied from 2.57 to 3.68 [7]. Our obtained pH value is lowest as compare to the commercial fruit drink was 4.2 found [8]. A group researcher reported that, the $\mathrm{pH}$ value in cucumber-melon drink was 4.89 [9]. 


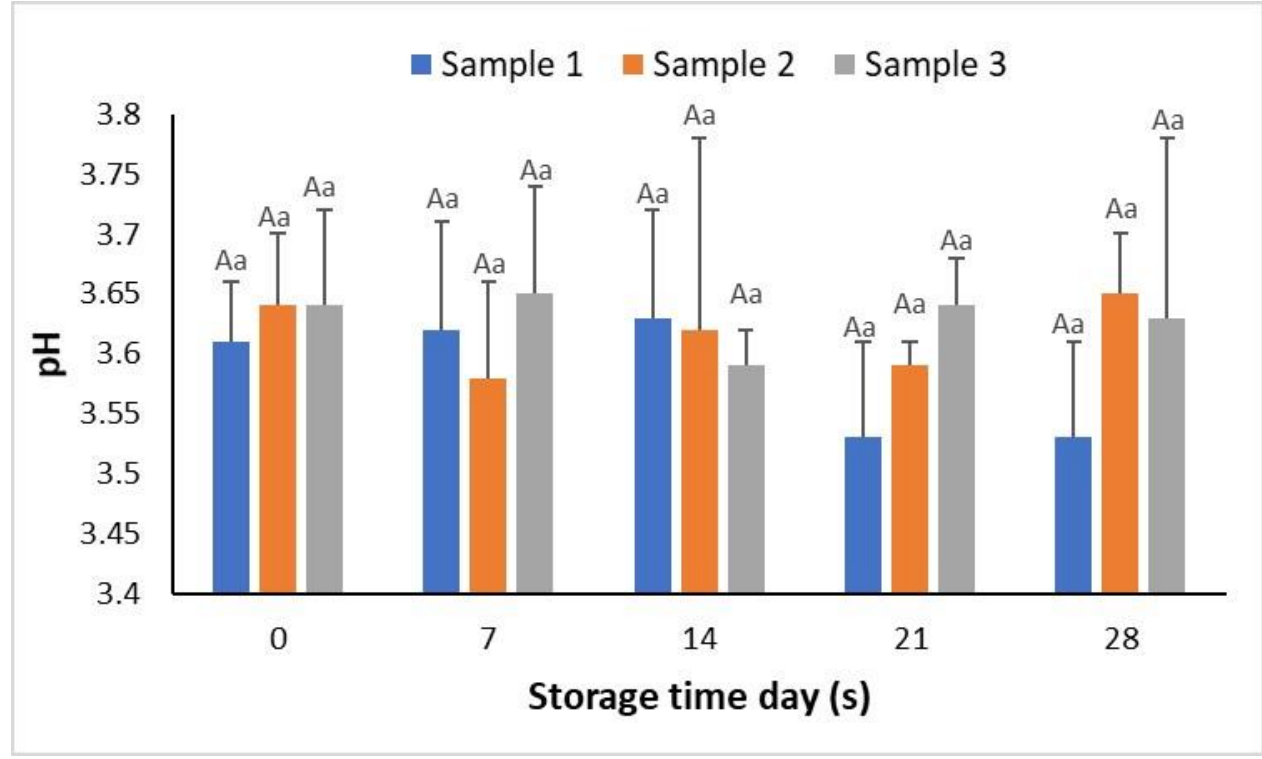

Figure 2. $\mathrm{pH}$ values of artificial litchi flavored drinks under storage

Means followed by different Uppercase letter of alphabets indicate significantly different $(\mathrm{P} \leq 0.05)$ within the sample in same day Means followed by different superscript lowercase letter of alphabets indicate significantly different(P $\leq 0.05)$ within the same sample every 7 days

\subsection{Acidity (\%) values of artificial litchi flavored drinks during storage}

The figure 3 shows the acidity $\%$ of artificial litchi drink during storage. The acidity values of artificial litchi drink ranged from 0.155 to $0.161 \%$ under the storage condition. The highest value and lowest value found in sample 3 after end of the storage. The acidity for all samples reduced with few exceptions from the beginning to the end period. Our obtained value is lower with the work of who found the acidity in cucumber-melon drink was $0.44 \%$ [9]. The mandarin (Citrus reticulata) diet drink retained the acidity about $0.51 \%$ which was higher than our work [10]. The variation in acidity might be due to the ingredient's variation, microbial metabolites formation.

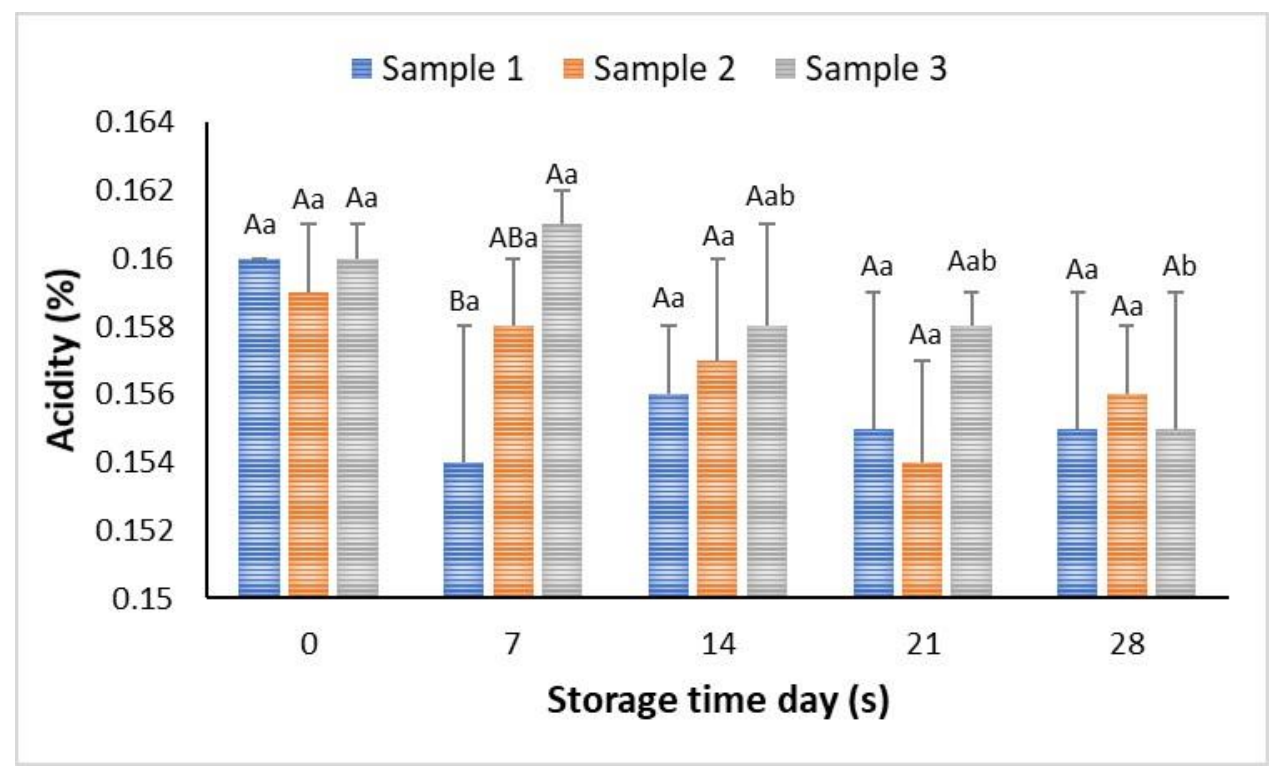

Figure 3. acidity (\%) values of artificial litchi flavored drinks during storage

Means followed by different Uppercase letter of alphabets indicate significantly different $(\mathrm{P} \leq 0.05)$ within the sample in same day Means followed by different lowercase letter of alphabets indicate significantly different(P $\leq 0.05)$ within the same sample every 7 days

\subsection{TSS ( $\left.{ }^{\circ} \mathrm{Brix}\right)$ values of artificial litchi flavored drinks under storage condition}

The TSS values of artificial litchi drinks has shown in figure 4 under storage condition. The values of TSS in artificial litchi drink varied from 15.43 to 16.10 ${ }^{\circ}$ Brix. The sample 2 found highest TSS value and lowest found in sample 3 under the entire storage duration. At the beginning, the values of TSS varied among the sample but there was no significant different $(\mathrm{P} \leq 0.05)$ found. The values for sample 1 and sample 3 increased till 14 days except sample 2 whereas the values for all samples was decreased at the end of the storage. Our obtained value of TSS was lower than the reco nstituted litchi juice was varied from $20-26^{\circ}$ Brix [6]. The TSS values of cucumber drink was ranged from 16 to $15.16^{\circ}$ Brix which was supported our obtained values [9]. The mandarin (Citrus reticulata) diet drink retained the TSS value about $18.8{ }^{\circ}$ Brix which was higher than our observed values [10,11]. The variation it might be due to the chemical reaction happen during increase storage duration as well as addition of solid content present in the samples. 


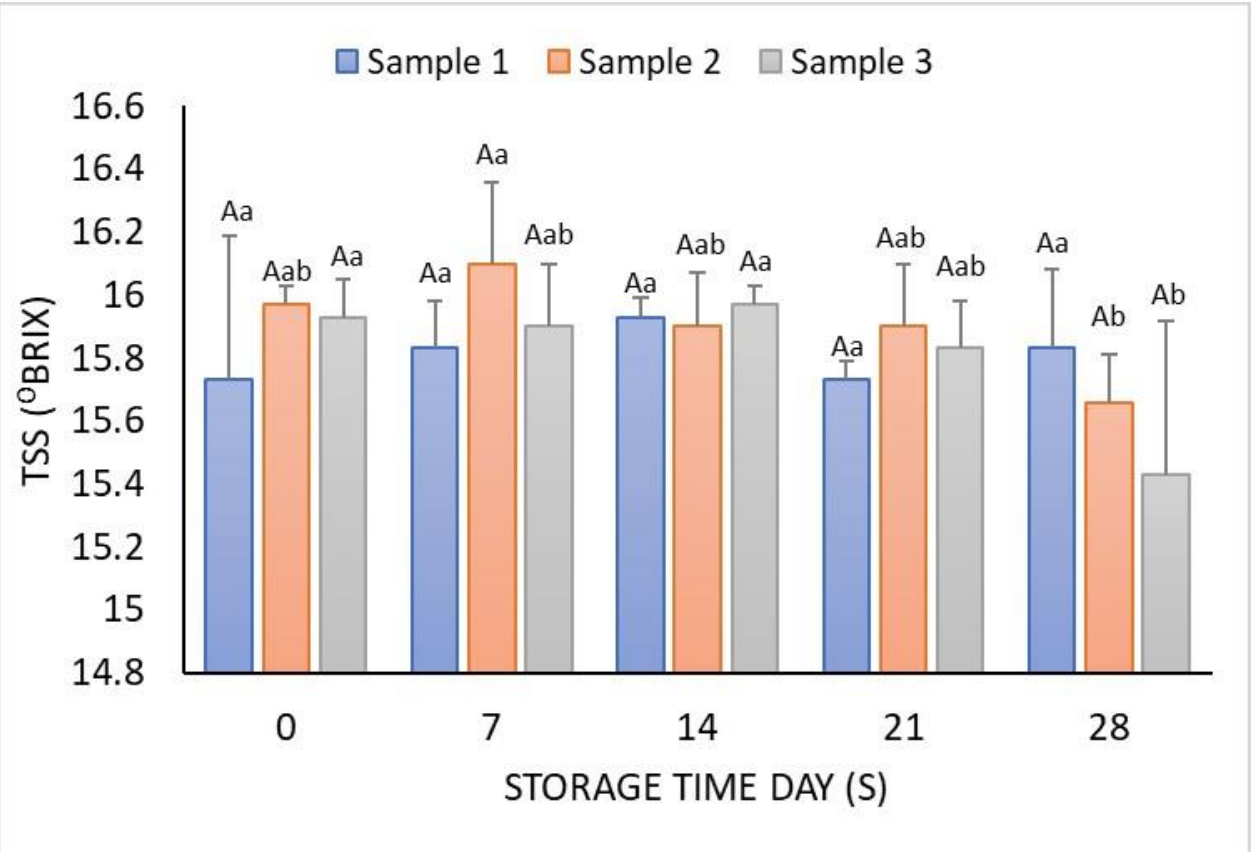

Figure 4. TSS ( ${ }^{\circ}$ Brix) values of artificial litchi flavored drinks during storage

Means followed by different Uppercase letter of alphabets indicate significantly different $(\mathrm{P} \leq 0.05)$ within the sample in same day Means followed by different lowercase letter of alphabets indicate significantly different $(\mathrm{P} \leq 0.05)$ within the same sample every 7 days

\subsection{Sensory characteristics of artificial litchi flavored drinks during storage}

The sensory characteristics of artificial litchi drinks during storage has shown in Table 2 The sensory profile of artificial litchi drink was evaluated in terms of color, flavor, taste and overall acceptability after 28 days of storage at ambient temperature $\left(30 \pm 2^{\circ} \mathrm{C}\right)$. At the very beginning $(0$ day), sample 1 found highest score and lowest in sample 2 for color value whereas sample 3 found highest score and lowest score found in sample 2 for the flavor score. On the other hand, sample 1 retained highest taste score and lowest taste score found in sample 2 whereas sample 1 found highest overall acceptability and lowest in sample 2. It is clearly observed that, the sensory parameters were followed the decreasing trend after end of the storage except sample 3 . Although, initially sample 3 found in lowest sensory acceptance but retained the more stable score under the entire storage period which is significantly different $(\mathrm{P} \leq 0.05)$ from other samples.

Table 2. The sensory characteristics of artificial litchi flavored drinks during storage.

\begin{tabular}{|c|c|c|c|c|c|}
\hline Day (s) & Sample & Color & Flavor & Taste & $\begin{array}{l}\text { Overall } \\
\text { acceptability }\end{array}$ \\
\hline \multirow{3}{*}{0} & 1 & ${ }^{\mathrm{A}} 6.87 \pm 1.46^{\mathrm{a}}$ & A5 $67 \pm 0.98^{\mathrm{a}}$ & ${ }^{\mathrm{A}} 6.00 \pm 1.31^{\mathrm{a}}$ & ${ }^{\mathrm{A}} 6.27 \pm 0.59^{\mathrm{a}}$ \\
\hline & 2 & в $5.67 \pm 1.11^{\mathrm{a}}$ & A $5.40 \pm 0.74^{\mathrm{a}}$ & А $5.53 \pm 1.30^{\mathrm{a}}$ & $\mathrm{AB} 5.67 \pm 0.90^{\mathrm{a}}$ \\
\hline & 3 & в $5.87 \pm 0.99^{\mathrm{a}}$ & A $5.87 \pm 1.19^{b}$ & А $5.87 \pm 1.30^{\mathrm{b}}$ & в $5.87 \pm 0.74^{\text {b }}$ \\
\hline \multirow{3}{*}{7} & 1 & $\mathrm{AB} 5.60 \pm 0.63^{\mathrm{b}}$ & $\mathrm{B} 4.80 \pm 1.08 \mathrm{~b}^{\mathrm{c}}$ & $\mathrm{B} 5.47 \pm 0.74^{\mathrm{a}}$ & в $4.93 \pm 0.70^{\mathrm{b}}$ \\
\hline & 2 & ${ }^{\mathrm{B}} 5.00 \pm 1.20^{\mathrm{ab}}$ & В $5.40 \pm 1.24^{\mathrm{a}}$ & ${ }^{\mathrm{A}} 6.33 \pm 1.11^{\mathrm{a}}$ & В $4.67 \pm 0.62^{\mathrm{b}}$ \\
\hline & 3 & ${ }^{\mathrm{A}} 6.40 \pm 1.40^{\mathrm{a}}$ & ${ }^{\mathrm{A}} 6.80 \pm 1.15^{\mathrm{a}}$ & ${ }^{\mathrm{A}} 6.93 \pm 1.10^{\mathrm{a}}$ & A $7.20 \pm 0.41^{\mathrm{a}}$ \\
\hline \multirow{3}{*}{14} & 1 & A5.53 $\pm 0.74 \mathrm{~b}$ & в $4.93 \pm 1.03^{\mathrm{ab}}$ & 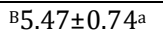 & в5.13 \pm 0.64 b \\
\hline & 2 & в $4.53 \pm 0.99$ bс & в $4.87 \pm 1.36^{\mathrm{ab}}$ & ${ }^{\mathrm{AB}} 6.13 \pm 1.68^{\mathrm{a}}$ & B $4.67 \pm 1.05^{\mathrm{b}}$ \\
\hline & 3 & A5.87 $\pm 1.46^{\mathrm{a}}$ & ${ }^{\mathrm{A}} 6.87 \pm 1.06^{\mathrm{a}}$ & А $6.87 \pm 0.99 \mathrm{a}$ & ${ }^{\mathrm{A}} 6.80 \pm 0.56^{\mathrm{a}}$ \\
\hline \multirow{3}{*}{21} & 1 & В $3.67 \pm 1.11^{\mathrm{c}}$ & В $4.00 \pm 0.85^{\mathrm{c}}$ & c $2.87 \pm 0.99 \mathrm{c}$ & B $4.07 \pm 1.62^{\mathrm{c}}$ \\
\hline & 2 & В $4.13 \pm 0.92^{\mathrm{c}}$ & B $4.20 \pm 1.32^{\mathrm{b}}$ & в $3.80 \pm 1.15^{\text {в }}$ & В $3.67 \pm 0.98^{\text {с }}$ \\
\hline & 3 & А $5.73 \pm 1.16^{\mathrm{a}}$ & ${ }^{\mathrm{A}} 6.07 \pm 1.28^{\mathrm{ab}}$ & ${ }^{\mathrm{A}} 6.33 \pm 1.05^{\mathrm{ab}}$ & А $5.73 \pm 0.70^{\mathrm{b}}$ \\
\hline \multirow{3}{*}{28} & 1 & в $4.07 \pm 1.39^{\mathrm{c}}$ & $\mathrm{B} 4.53 \pm 1.30^{\mathrm{bc}}$ & в3.87 $\pm 1.92^{\text {b }}$ & B $4.13 \pm 0.92^{\mathrm{c}}$ \\
\hline & 2 & в $4.07 \pm 1.03^{\mathrm{c}}$ & в $4.27 \pm 0.59$ b & $\mathrm{C} 2.80 \pm 1.01^{\mathrm{c}}$ & в $3.60 \pm 1.18$ с \\
\hline & 3 & А $5.87 \pm 0.92^{\mathrm{a}}$ & ${ }^{\mathrm{A}} 6.27 \pm 1.10^{\mathrm{ab}}$ & А $5.73 \pm 1.16^{\mathrm{b}}$ & А $5.87 \pm 0.83^{\mathrm{b}}$ \\
\hline
\end{tabular}

A-C Means followed by different superscript letter of alphabets in each column significantly different (P $\leq 0.05)$ within the sample in same day a-c Means followed by different superscript letter of alphabets in each column significantly different(P $\leq 0.05)$ within the same sample every 7 days

\subsection{Conclusion}

In this study, $\mathrm{pH}$, acidity, TSS and sensory characteristics of three formulated samples were investigated under 28 days of storage at ambient temperature. Considering $\mathrm{pH}$, acidity, TSS values under entire storage condition the formulation of sample 3 had shown better results although with few exceptions there was no significantly different among the samples. The sensory profile of three different formulation was evaluated in terms of color, flavor, taste and overall acceptability. The sensory parameters were followed the decreasing trend after end of the storage except sample 3 . Although, initially sample 3 found in lowest sensory acceptance but retained the more stable score under the entire storage period which is significantly different (P $\leq 0.05)$ from the other samples. However, end of the study we recommended that, the formulation of sample 3 had better among other sample 1 and sample 2 in terms of quality and cost. 


\subsection{References}

[1] S. Ahammed, M. Talukdar, and M. Kamal, “Development of value-added products from home-grown lychee”, J. Environ. Sci. Nat. Resour., Vol. 7, Pp. 121125,2014

[2] T. Sarkar, P. Nayak, and R. Chakraborty, “Litchi (Litchi chinensis Sonn.) Products and processing technologies: An Update”, Ambient Sci., Vol. 5, Pp. 11$16,2018$.

[3] M.K. Khan, M.N. Asif, M.H. Ahmad, M. Imran, M.S. Arshad, S. Hassan, M.I. Khan, M.U. Nisa, M.M. Iqbal, and N. Muhammad, “Ultrasound-assisted optimal development and characterization of stevia-sweetened functional beverage”, J. Food Qual., Pp. 1-6, 2019.

[4] A. Saeid, A. Rahman, R.H. Utsob, U. Hosen, and M. Islam, "Development and quality assessment of honey nut drink”, Malaysian Journal of Halal Research, Vol. 4, Pp. 6-10, 2021. https://doi.org/10.2478/mjhr-2021-0002 (In Press)

[5] M.C. Roy, M. Alam, A. Saeid, B.B. Das, M.B. Mia, M.A. Rahman, J.B. Eun, and M. Ahmed, "Extraction and characterization of pectin from pomelo peel and its impact on nutritional properties of carrot jam during storage”, J. Food Process. Preser., Vol. 42, Pp. e13477, 2018. https://doi.org/10.1111/jfpp.13411

[6] R.S. Singh, and P. Kaur, “Evaluation of litchi juice concentrate for the production of wine”, Ind. J. Nat. Prod. Resour., Vol. 8, Pp. 386-391, 2009.

[7] A. Reddy, D.F. Norris, S.S. Momeni, B. Waldo, and J.D. Ruby, “The pH of beverages in the United States”, J. American Dent. Assoc., Vol. 147, Pp. 255-263, 2016.

[8] C.P. Champagne, and N.J. Gardner, "Effect of storage in a fruit drink on subsequent survival of probiotic lactobacilli to gastro-intestinal stresses", Food Res. Int., Vol. 41, Pp. 539-543, 2008.

[9] H. Kausar, S. Saeed, M.M. Ahmad, and A. Salam, "Studies on the development and storage stability of cucumber-melon functional drink", J. Agric. Res., Vol. 50, Pp. 239-248, 2012.

[10] M. Ahmed, A. Ahmad, Z.A. Chatha, and S.M.R. Dilshad, "Studies on preparation of ready to serve mandarin (citrus reticulata) diet drink", Pak. J. Agric. Sci., Vol. 45, Pp. 470-476, 2008.

[11] FAO., "Lychee Production in the Asia-Pacific Region”, Lychee Production in the Asia-Pacific Region, Pp. $128,2002$. 